\title{
How Small Business Owners Can Overcome Terrible Regulations
}

\author{
John Kramer (Institute for Justice) \\ Nick Sibilla (Institute for Justice)
}

KEYWORDS: Management of Companies \& Enterprises, Entrepreneurship, Family Business, Legal.

Regulations can destroy even the best entrepreneurial dream. To help entrepreneurship thrive in this nation, Institute for Justice (IJ) a public interest law firm that has successfully defended the constitutional rights of entrepreneurs nationwide, recently published an Entrepreneur's Survival Guide. This free report provides practical advice for aspiring entrepreneurs to fight for their right to get into business. The guide is a collection of lessons learned by IJ advocates through decades of experience fighting on behalf of those who want to earn an honest living in the occupation of their choice, but find needless government regulation in their way. Among the topics covered in the guide are how to build a grassroots organization to fight red tape and other barriers to economic liberty, and how to work with media outlets to advance your efforts.

The expansion of government regulation in the private economic affairs of Americans is well documented, and nowhere more so than in the area of occupational licensing where individuals must first obtain the government's permission to get into business. In the 1950s, only one in 20 American workers needed a government-issued license to work; today, that figure has skyrocketed to one in three. That's far higher than the number of Americans who earn the minimum wage or have joined a union.

It makes sense to license doctors or other occupations where one might reasonably presume a need for government-mandated education and testing. But consider that some states require a license to shampoo hair, trim trees, tell fortunes or even sell flowers. Many of these restrictions don't protect consumer health or safety, but rather are clearly designed to limit competition -- hardly an appropriate use of government power. For instance, in 24 states, African hair braiders must spend at least 1,000 hours in training to get a cosmetology license, even though students never

receive even a single hour of training on how to braid hair. And nearly half of America's 50 biggest cities ban food trucks from vending "too close" to a brick-andmortar restaurant, thus hindering competition. Likewise, more than three-fifths of America's 50 largest cities artificially limit the number of taxis that can operate, thus allowing the government, rather than would-be drivers and consumers, to decide how many cabs should operate on the streets.

No wonder a recent survey of more than 12,000 entrepreneurs

(http://www.thumbtack.com/survey\#/2014/1/states) found that "the friendliness of professional licensing requirements was the most important regulatory issue in determining a state's overall friendliness to small businesses."

To help small-business owners who want to survive in the face of such restrictions on their economic liberty, here are just a few of the many pieces of advice the Entrepreneur's Survival Guide has to offer:

\section{Grassroots Organization}

When building a new group dedicated to eliminating red tape, it is vital to identify other entrepreneurs and potential allies. Think not only of businesses that are or could be affected by the regulations, but also any other stakeholders that may be interested: business groups, civic organizations, nonprofits, would-be consumers and academics. If a regulatory agency is threatening other small-business owners with cease-and-desist letters, that information can sometimes be obtained through a public records request.

The first meeting of any such grassroots group is key to forging an effective organization. Developing a clear mission and objective keeps the group focused and helps it stay on message. To inform supporters of the

Copyright $\odot 2014$ The Authors. Entrepreneur \& Innovation Exchange is published at EIX.org. This is an open access article under the terms of the Creative Commons Attribution-NoDerivs License, which permits use and distribution in any medium, provided the original work is properly cited and 
latest updates, be sure to use a sign-in sheet to collect contact information from attendees, especially their email addresses and cell phone numbers.

To prevent disengagement, make sure the organization has a detailed strategy for moving forward with clear short-term goals that team members are assigned to accomplish by a set date. Additionally, too many meetings or calls to action can trigger burnout. So mobilize supporters only when necessary; hold meetings only when needed; and keep these meetings short and succinct.

\section{Media}

Working with local media outlets can be a great way to earn free publicity for a cause. When the group is ready, announce its formation with a media blitz. Send out press releases and, if there is enough interest, hold a press conference to make the announcement.

When pitching the media to cover your story, always ask journalists if they are on deadline. If not, ask to make a 30-second pitch about your battle. Respect each reporter's time by keeping the initial pitch short and to the point.

If a media outlet contacts your organization for an interview, craft three brief but compelling talking points ahead of time to summarize what you are trying to accomplish and why an ordinary person should care. Many reporters are just looking for a great quote or sound bite; be sure to give it to them. Remember to never say or do anything you wouldn't want to see in print or on the news.

In addition to pitching journalists and appearing on camera, organizations can write op-eds and letters to the editor. Op-eds are guest columns to a newspaper or magazine; they usually run from 500 to 800 words and should clearly state the issue and explain what needs to be done. They should also be written in a way that grabs the reader's attention. If there is enough space, try to think of opponents' possible rebuttals and counter them in the op-ed. In a similar vein, a letter to the editor lets the writer respond to an article or editorial that ran in that outlet. Because they are shorter than op-eds (typically about 150 words), letters should zero in to make only one point.

\section{Legislation}

Just because a law is on the books, that doesn't mean it must stay there. Laws are reformed all the time thanks to the work of ordinary Americans. After researching the laws you want to challenge, identify what your grassroots group would be willing to concede to promote reform and what would not be negotiable. But never compromise too early or too easily.

Once the reform has been introduced in either the city council or state legislature, identify lawmakers individually and, if possible, learn what their interests, constituencies and concerns are. The committee chair who hears the legislation is particularly important because he or she typically has the power to move bills forward. Ensuring you have some group members at every hearing demonstrates to lawmakers how committed your organization is to advancing reforms. Mobilize all your supporters only for major legislative events, such as committee or full-chamber votes.

\section{Social Media}

Twitter has nearly 300 million monthly active users. Facebook is even more staggering, with more than 1 billion monthly active users worldwide. Thanks to their extensive reach, social media can be a highly costeffective way to inform supporters and allies, and leverage that support into action. (As part of the online compendium to the Entrepreneur's Survival Guide, the Institute for Justice has outlined step-by-step processes for business owners to create their own new social media accounts.)

When Washington, D.C., debated new regulations for the city's budding food truck industry, these mobile entrepreneurs sprang into action. With help from the Institute for Justice, food truck owners passed out fliers to their hungry customers, urging people to sign petitions online, contact council members and tweet with the hashtag \#SaveDCFoodTrucks. Their battle became a hot media story, with local TV stations and The Washington Post regularly reporting on the latest developments. Food trucks even held a protest where food trucks parked in their regular spots, but didn't serve anyone food, "a demonstration of what the lunch hour could be like under new regulations proposed by city officials."

"Social media enabled us to quickly mobilize thousands of District residents and workers to contact the mayor and D.C. Council when we needed them the most, providing an effective counterweight to a small but powerful group of special interests trying to shut us 
down," noted Che Ruddell-Tabisola, co-owner of BBQ Bus and the executive director of the DMV Food Truck Association, which was founded to reform the city's laws.

Ultimately, all that hard work paid off when the city council rejected attempts to clamp down on food trucks and instead reformed the District's vending laws. Using tactics refined in its fight in Washington, D.C., the DMV Food Truck Association has since helped open up nearby Fairfax County and Alexandria, Va., to food trucks and has inspired many other similar efforts nationwide.

Small businesses are the backbone of America's economy. By using the Entrepreneur's Survival Guide, entrepreneurs can strengthen their spines in their fight against government officials who abuse their power with the goal of protecting entrenched interests rather than the rights of all entrepreneurs.

John Kramer and Nick Sibilla work at the Institute for Justice.

Additional Search Terms: bad regulations, regulation is hurting my business, laws that restrict business, legal problems, law, changing laws 